\title{
FAKTOR INTERNAL DAN EKSTERNAL DALAM PERKEMBANGAN USAHA KOPERASI DI KOTA MAGELANG
}

\author{
Siti Noor Khikmah \\ Universitas Muhammadiyah Magelang \\ e-mail: noorkhikmah@yahoo.com
}

\begin{abstract}
ABSTRAK
The purpose of this study was to test empirically that internal factors (member participation, solidarity among members, education and leadership management, business scale; capital development; managerial skills; market network, the number and quality of human resources; ownership and utilization of production technology and information; management system ; the performance of the board; similarity of interests of members) and external factors (government commitment; infrastructure systems; services, education and counseling; supporting climate; lifting of government facilities; price level) affect the development of cooperatives in the city of Magelang. The sample was 34 and the cooperative management that can be processed by 27 respondents. Analysis of the data used is multiple regression. Results of fieldwork states that the board of education and leadership has a positive effect on the development of a cooperative effort. This study can not prove the other internal factors and external factors affect the development of a cooperative effort. The test results of the adjusted $R^{2}$ menghaslkan $34.9 \%$ while the remaining $65.1 \%$ is influenced by other fakor outside the research model.
\end{abstract}

Keywords: The internal factors and eksternal factors, the development of cooperatives

\section{PENDAHULUAN}

Salah satu lembaga yang sesuai dengan pembangunan masyarakat dalam upaya pemberdayaan ekonomi rakyat adalah koperasi. Koperasi memiliki prinsip gotong royong, rasa kebersamaan dan rasa kekeluargaan. Organisasi koperasi yang diperlukan masyarakat adalah koperasi yang jujur dan dinamis sehingga potensi anggota dalam menghimpun dana dapat terwujud (Badaruddin dkk, 2005).

Pembangunan koperasi identik dengan mengatasi kemiskinan. Menurut Mubyarto (2003:10), koperasi yang berazaskan pasal 33 UUD 1945 merupakan satu-satunya jalan untuk mendekatkan jurang perbedaan antara yang kaya dengan yang miskin. Koperasi dipandang sebagai lembaga yang menjalankan kegiatan usaha tertentu, berupa pelayanan kebutuhan keuangan atau perkreditan, kegiatan pemasaran dan kegiatan lain. Koperasi telah menjadi alternatif bagi masyarakat yang telah merasakan bahwa manfaat dan peran koperasi lebih baik dibandingkan dengan lembaga lain. Koperasi juga menjadi organisasi yang dimiliki oleh anggotanya. Rasa memiliki dinilai telah menjadi faktor utama yang menyebabkan koperasi mampu bertahan pada berbagai kondisi sulit, yaitu dengan mengandalkan loyalitas anggota dan kesediaan anggota untuk bersama-sama koperasi menghadapi kesulitan. 
Kegiatan usaha yang dikembangkan koperasi pada prinsipnya adalah kegiatan yang berkaitan dengan kepentingan anggota. Salah satu indikator utama keberhasilan kegiatan usaha adalah usaha anggota yang berkembang sejalan dengan perkembangan usaha koperasi. Keberhasilan atau kegagalan koperasi ditentukan oleh keunggulan komparatif koperasi, yaitu dalam kemampuan koperasi berkompetisi memberikan pelayanan kepada anggota dan dalam usahanya tetap hidup (survive) dan berkembang dalam melaksanakan usaha.

Koperasi merupakan badan usaha yang bertujuan untuk mensejahterakan anggota atau masyarakat dalammenjalankan tugasnyamemiliki beberapa faktor yang dapat mempengaruhi maju atau tidaknya suatu koperasi. Beberapa masalah pokok yang masih membelit koperasi, dan perlu dipecahkan secara bersama-sama adalah, kesadaran berkoperasi belum tumbuh berakar di kalangan masyarakat Indonesia, minimnya peran anggota dalam organisasi koperasi, koperasi tidak berkembang dengan cepat seperti Badan Usaha Milik Negara/swasta karena partisipasi dan peran serta anggota koperasi sangat minim, pengelolaan koperasi dan usaha, termasuk pengawasan masih sangat lemah karena kekurangmampuan pengurus, manajer dan pembina.

Permasalahan mikro yang sangat mempengaruhi kinerja koperasi, yaitu anggota koperasi cenderung hanya sebagai pemilik tetapi bukan sebagai pengguna yang diindikasikan dari rendahnya keterkaitan usaha antar nggota dan koperasi yang secara langsung mempengaruhi rendahnya manfaat koperasi buat anggota, kepentingan bisnis koperasi lebih diutamakan (menyolok) daripada kepentingan anggotanya, partisipasi anggota sebagai pemilik dan pengguna sangat rendah, rasa kebersamaan diantara anggota maupun antara anggota dengan koperasi juga hampir tidak ada, kaderisasi sangat jarang dilakukan dan jika ada sifatnya temporary atau tidak berkesinambungan serta proses penyuluhan, pendidikan dan pelatihan tidak berjalan dengan baik dan berkesinambungan serta hasil-hasil penelitian ataupun pemikiran ilmiah tidak pernah dimanfaatkan sebagai bahan masukan dalam pengambilan keputusan oleh para pengambil kebijaksanaan.

Penelitin yang dilakukan Handayani (2007) menyatakan bahwa faktor yang mempengaruhi perkembangan usaha koperasi yaitu komitmen pemerintah dalam menempatkan koperasi sebagai soko guru perekonomian, sistem prasarana, pelayanan, pendidikan dan penyuluhan, iklim pendukung perkembangan koperasi, perkembangan modal, ketrampilan manajerial, jaringan pasar, jumlah dan kualitas SDM, perkembangan omzet pelayanan dan asset produksi, tingkat partisipasi anggota, pemilikan dan pemanfaatan perangkat teknologi dan informasi, sistem manajemen dukungan dari perusahaan sendiri, patner bisnis dan kinerja pengurus. Terdapat tiga faktor tidak dapat diproses lebih lanjut karena tidak berpengaruh yaitu komitmen pemerintah dalam menempatkan koperasi sebagai soko guru perekonomian, jaringan pasar dan sistem manajemen.

Penelitian Rachman (2006) menjelaskan faktor yang berpengaruh terhadap perkembangan usaha KUD yaitu profesionalisme pengurus, partisipasi anggota, pembinaan pemerintah, kemitraan usaha dan iklim usaha. Hasil analisis pertama yaitu faktor profesionalisme pengurus, partisipasi anggota, dan kemitraan usaha dengan besarnya pengaruh masing-masing faktor secara berurutan sebesar $12,5 \%, 27,2 \%$, dan $24,9 \%$, sedangkan faktor pembinaan pemerintah dan iklim usaha kurang berpengaruh terhadap perkembangan volume usaha. Adapun faktor yang berpengaruh terhadap perkembangan SHU yaitu profesionalisme pengurus, partisipasi anggota, pembinaan pemerintah dan iklim usaha dengan besarnya pengaruh masingmasing sebesar $45,7 \%, 21,2 \%, 33,3 \%$ dan $26 \%$, sedangkan kemitraan usaha kurang berpengaruh 
terhadap perkembangan SHU. Secara simultan profesionalisme pengurus, partisipasi anggota, pembinaan pemerintah, kemitraan usaha dan iklim usaha berpengaruh terhadap perkembangan usaha KUD baik melalui volume usaha maupun melalui SHU.

Penelitian Ratna (2009) menghasilkan bahwa partisipasi angggota, solidaritas antar anggota koperasi, pengurus koperasi yang juga tokoh masyarakat, skala usaha, perkembangan modal, ketrampilan manajerial, jaringan pasar, jumlah dan kualitas sumber daya manusia, pemilikan dan pemanfaatan teknologi produksi dan informasi, sistem manajemen, kinerja pengurus, komitmen pemerintah untuk menempatkan koperasi sebagai soko guru perekonomian nasional, sistem prasarana, pelayanan, pendidikan dan penyuluhan, iklim pendukung perkembangan koperasi, dicabutnya fasilitas tertentu oleh pemerintah, dan tingkat harga mempengaruhi perkembangan usaha Koperasi Unit Desa Jalandara Kabupaten Sidoarjo.

Penelitian ini pengembangan dari penelitian Handayani (2007), perbedaan pertama menambah variabel kesamaan kepentingan ekonomi anggota dengan alasan bahwa seseorang menjadi anggota koperasi umumnya mempunyai tujuan kepentingan ekonomi yang sama untuk mendapatkan dana pinjaman dan sisa hasil usaha (SHU). Kedua, lokasi yang digunakan di Kota Magelang karena banyak koperasi tetapi koperasi yang aktif atau sehat hanya sedikit. Seperti yang dilakukan pada penilaian kesehatan terhadap 40 koperasi simpan pinjam (KSP) dan Koperasi Jasa Keuangan Syariah (KJKS) yang dilakukan Dinas Koperasi dan UMKM Jateng. Dari jumlah 40 hanya 12 koperasi yang berstatus sehat, sementara hasil lainnya 26 koperasi predikatnya kurang sehat dan 3 (tiga) koperasi masih kurang sehat ternyata masih ada tiga KSP dan KSU di Klaten, Magelang serta Semarang yang berada dalam kondisi kurang sehat, (Suara Merdeka, 2009). Hal ini menjadi perhatian pemerintah kota.
Berdasarkan alasan yang ada maka dapat dirumuskan dalam bentuk pertanyaan sebagai berikut: 1). Apakah faktor internal yang terdiri dari partisipasi angggota, solidaritas antar anggota koperasi. pengurus koperasi yang juga tokoh masyarakat, skala usaha, perkembangan modal, ketrampilan manajerial, jaringan pasar, jumlah dan kualitas sumber daya manusia, pemilikan dan pemanfaatan teknologi produksi dan informasi, sistem manajemen, kinerja pengurus, komitmen pemerintah untuk menempatkan koperasi sebagai soko guru perekonomian nasional, dan kesamaan kepentingan ekonomi anggota berpengaruh terhadap perkembangan usaha koperasi? 2) Apakah faktor eksternal yang terdiri dari sistem prasarana; pelayanan, pendidikan dan penyuluhan; iklim pendukung perkembangan koperasi; dicabutnya fasilitas tertentu oleh pemerintah; dan tingkat harga berpengaruh terhadap perkembangan usaha koperasi? Tujuan penelitian 1) memberikan bukti secara empiris faktor internal dan faktor eksternal terhadap perkembangan usaha koperasi di Kota Magelang.

\section{REVIEW LITERATUR DAN HIPOTESIS}

\section{Koperasi}

Koperasi berasal dari kata "cooperation" yang artinya kerjasama. Koperasi adalah suatu perkumpulan orang, biasanya memiliki kemampuan ekonomi terbatas, yang melalui suatu bentuk organisasi perusahaan yang diawasi secara demokratis, masing-masing memberikan sumbangan yang setara terhadap modal yang diperlukan, dan bersedia menaggung resiko serta menerima imbalan sesuai dengan usaha yang mereka lakukan (Widayati, 2005:6). Menurut UU Koperasi Tahun 1967 No.12 tentang pokokpokok perkoperasian dalam Anaroga dan Sudantoko (2002:15) koperasi Indonesia adalah organisasi ekonomi rakyat yang berwatak sosial, beranggotakan orang-orang dan badan hukum koperasi yang merupakan tata susunan ekonomi 
sebagai usaha bersama berdasarkan atas azas kekeluargaan.

Landasan ideal koperasi adalah dasar atau landasan yang digunakan dalam usaha untuk mencapai cita-cita koperasi yaitu Pancasila, dengan pertimbangan Pancasila merupakan pandangan hidup dan ideologi bangsa. Landasan struktural koperasi sebagai tempat berpijak koperasi dalam susunan hidup bermasyarakat adalah Undang-Undang Dasar 1945 yang merupakan aturan pokok Indonesia. Landasan mental koperasi Indonesia adalah rasa setia kawan dan kesadaran berpribadi. Suatu koperasi harus tergabung dua landasan mental yang saling dorong mendorong, yaitu setia kawan dan kesadaran berpribadi (Anoraga dan Sudantoko, 2002:14). Azas koperasi Indonesia adalah gotong royong dan kekeluargaan yang sesuai dengan kepribadian bangsa Indonesia, yang menjadi ciri watak sosial koperasi sebagai pelaku ekonomi.

\section{Tujuan dan Peranan Koperasi}

Sebagai badan usaha koperasi mempunyai tujuan dalam melaksanakan kegiatannya, yaitu untuk mencari keuntungan. Selain mencari keuntungan (profit oriented), yang sebesar-besarnya, koperasi juga tetap mengutamakan kesejahteraan anggotanya. Sesuai pasal 3 UU koperasi tujuan utama koperasi adalah memajukan kesejahteraan anggota dan dapat memperluas usaha ke masyarakat disekitar, sehingga diharapkan koperasi dapat berperan dalam meningkatkan taraf hidup masyarakat. Pada pelaksanaannya koperasi mempunyai dua fungsi, yaitu fungsi sosial yaitu memupuk persaudaraan dan kekeluargaan secara gotong royong, dan fungsi ekonomi yaitu memperjuangkan kemakmuran bersama secara merata bagi para anggota koperasi.

\section{Bentuk dan Jenis-jenis Koperasi}

Menurut Firdaus dan Agus (2004:61), tingkatan organisasi koperasi sesuai dengan tingkat daerah administrasi pemerintahan, yaitu a). Koperasi primer, dibentuk sekurang- kurangnya 20 orang yang telah memenuhi syaratsyarat keanggotaan sebagaimana ditentukan dalam Undang-Undang. b). Pusat koperasi, tediri dari sekurang-kurangnya 5 koperasi primer yang telah berbadan hukum, yang daerah kerjanya adalah daerah tingkat II (tingkat kabupaten). c). Gabungan koperasi, terdiri dari sekurangkurangnya 3 pusat koperasi yang berbadan hukum, yang daerah kerjanya adalah daerah tingkat I (tingkat propinsi). d). Induk koperasi, terdiri dari sekurang-kurangnya 3 gabungan koperasi yang berbadan hukum,yang daerah kerjanya adalah Ibukota Negara RI (tingkat nasional).

\section{Permodalan dan Perangkat Koperasi}

Walaupun bukan merupakan bentuk perkumpulan modal tetapi sebagai suatu badan usaha, koperasi dalam menjalankan usahanya harus tetap memiliki modal, merupakan salah satu faktor produksi yang sangat penting. Menurut UU No. 25 pasal 41 tentang perkoperasian dijelaskan bahwa modal koperasi terdiri dari:

a. Modal sendiri, terdiri dari simpanan pokok, simpanan wajib, dana cadangan, hibah.

b. Modal pinjaman, terdiri dari pinjaman anggota, pinjaman koperasi lain, bank, penerbitan obligasi, dan sumber lain yang sah.

c. Modal penyertaan adalah modal yang bersumber dari pemerintah atau masyarakat dalam bentuk investasi.

Suatu koperasi mempunyai perangkat yang terdiri dari a).Rapat anggota, merupakan pemegang kekuasaan tertinggi dalam koperasi. b).Pengurus, dipilih dari dan oleh anggota koperasi dalam rapat anggota dengan masa jabatan paling lama 5 tahun dan jika sudah habis masa jabatannya dapat dipilih kembali. c).Pengawas, merupakan perangkat organisasi koperasi yang bertugas melakukan pengawasan terhadap pelaksanaan kebijakan dan pengeloaan koperasi. Koperasi mempunyai prinsip-prinsip yang harus ada yaitu 1).Keanggotaan yang bersifat sukarela dan terbuka, 2). Pengelolaan 
dilakukan secara demokratis 3). Kemandirian 4) Pendidikan perkoperasian 5) Kerjasama anggota 6) Pembagian SHU yang dilakukan secara adil sesuai dengan jasa para anggota. Pembagian ini ditetapkan dalam rapat anggota sesuai dengan anggaran dasar.

a. Pembagian SHU digunakan untuk cadangan, pengurus, anggota, sosial.

b. Kalau untuk owners ; SHU diukur dari penyertaan modal atau total simpanan

c. Kalau untuk customer; SHU diukur dari beberapa kontribusi terhadap pembentukan SHU ( koperasi)

d. Kalau untuk koperasi simpan pinjam; diukur dari seberapa sering ia meminjam, semakin sering semakin besar SHU.

e. Kalau untuk koperasi konsumsi :diukur dari volume konsumsi per tahun.

\section{Hipotesis}

\section{Faktor yang mempengaruhi Perkembangan} Usaha Koperasi

\section{Faktor Internal}

\section{a. Partisipasi Anggota terhadap perkem- bangan usaha koperasi}

Partisipasi merupakan faktor penting dalam mendukung keberhasilan atau perkembangan suatu organisasi. Melalui partisipasi segala aspek yang berhubungan dengan pelaksanaan kegiatan pencapaian tujuan direalisasikan. Hendar dan Kusnadi (2005:91), menyatakan bahwa partisipasi dikembangkan untuk menyatakan atau menunjukkan peran serta (keikutsertaan) seseorang atau kelompok orang dalam aktivitas tertentu, sedangkan partisipasi anggota dalam koperasi berarti mengikutsertakan anggota koperasi itu dalam kegiatan operasional dan pencapaian tujuan bersama. Tingkat partisipasi anggota pada koperasi-koperasi saat ini masih cukup banyak yang belum maksimal. Hal ini menunjukkan kurang tumbuhnya rasa memiliki dari anggota sehingga masih memanfaatkan jalur lain dalam memenuhi kebutuhannya. Penelitian
Rachman (2006) menyatakan bahwa partisipasi anggota berpengaruh terhadap perkembangan koperasi.

H1a : Partisipasi anggota berpengaruh positif terhadap Perkembangan Usaha Koperasi

\section{b. Solidaritas antar anggota koperasi ter- hadap perkembangan usaha koperasi}

Berkoperasi juga dimaknai sebagai upaya membangun ikatan solidaritas antar anggota, karena dengan ikatan ekonomi, ikatan solidaritas bisa dibangun secara lebih kongkrit. Ikatan solidaritas ini pada kenyataannya juga bisa dikembangkan untuk meraih tujuan gerakan yang lebih besar (Soedirman , 2006: 4). Hasil tersebut dapat dikatakan bahwa adanya solidaritas yang kuat antar anggota koperasi dapat menjadi suatu kekuatan didalam mencapai tujuan koperasi.

H1b: Solidaritas anggota berpengaruh positif terhadap perkembangan usaha Koperasi

\section{c. Pengurus Koperasi yang juga tokoh masyarakat terhadap perkembangan usaha koperasi}

Pengurus koperasi yang juga tokoh dalam masyarakat sehingga rangkap jabatan ini menimbulkan fokus perhatian terhadap pengelolaan koperasi berkurang sehingga kurang menyadari adanya perubahan lingkungan(Sumarsono, 2003:124). Dapat diketahui bahwa dengan adanya rangkap jabatan yang dimiliki oleh pengurus koperasi menyebabkan kurang profesionalismenya pengurus dalam mengelola koperasi.

H1c: Pengurus koperasi berpengaruh positif terhadap Perkembangan Usaha Koperasi

\section{d. Skala Usaha terhadap perkembangan usaha koperasi}

Skala usaha yang belum layak, karena kemampuan pemasaran yang masih terbatas pada beberapa jenis komoditi, dan belum terbinanya jaringan dan mata rantai pemasaran prduk koperasi secara terpadu menyebabkan koperasi sulit untuk berkembang(Sumarsono, 2003:124). 
Dapat dikatakan bahwa dengan skala usaha yang kecil yang dilaksanakan oleh koperasi menyebabkan koperasi sulit untuk berkembang.

H1d: Skala Usaha koperasi berpengaruh positif terhadap Perkembangan Usaha Koperasi

\section{e. Perkembangan Modal terhadap per- kembangan usaha koperasi}

Perkembangan modal dalam koperasi sangat mempengaruhi perkembangan usaha koperasi karena dengan modal yang cukup besar koperasi dapat mengembangkan usahanya lebih banyak lagi. Soedirman (2006:3) menyatakan bahwa apabila koperasi ingin mengembangkan usahanya kepasar global maka koperasi membutuhkan modal yang banyak, karena di pasar global terdapat resiko bisnis yang cukup tinggi. Kebanyakan koperasi belum mampu menggalang pemupukan modal dari anggota koperasi sendiri selain dari iuran pokok dan iuran wajib anggota. Penggalangan dana dari dana pribadi anggota yang disimpan di dalam bentuk simpanan sukarela masih sulit diharapkan. Hal ini tidak lain karena masih kurangnya keyakinan anggota bahwa dengan cara bersama-sama membesarkan modal koperasi justru anggota akan menikmati manfaat koperasi yang lebih besar

H1e: Perkembangan Modal koperasi berpengaruh positif terhadap perkembangan usaha Koperasi

\section{f. Ketrampilan manajerial terhadap per- kembangan usaha koperasi}

Menurut Soedirman (2006:3) menyatakan bahwa ketrampilan manajerial sebenarnya saling berkaitan dengan kualitas sumber daya insani dan masih kurangnya pelatihan-pelatihan yang diselenggarakan oleh koperasi yang bersangkutan. Bahwasannya ketrampilan manajerial di koperasi sangat penting karena organisasi yang baik adalah organisasi yang memiliki manajemen yang baik dan terarah.
H1f : Ketrampilan manajerial berpengaruh positif terhadap Perkembangan Usaha Koperasi

\section{g. Jaringan Pasar terhadap perkembangan usaha koperasi}

Jaringan pasar merupakan suatu tempat untuk mencari pangsa pasar yang lebih luas agar dapat memperoleh kentungan yang lebih besar. Pelayanan koperasi umumnya terfokus pada internal koperasi yang belum terbentuk jaringan antar koperasi. Koperasi akan lebih berdaya saing jika koperasi mampu membentuk jaringan usaha. Melalui jaringan yang kuat, koperasi akan mampu berkiprah di pasar global dengan meningkatkan mutu pelayanan (Soedirman, 2006:3). Jaringan adalah suatu faktor pendukung yang mempunyai kekuatan yang menentukan dalam melaksanakan usaha ekonomi dan program lainnya. Adanya jaringan yang kuat dalam suatu lembaga akan mampu bertahan dan berkembang dalam jangka panjang dan lebih mampu mengantisipasi goncangan yang mungkin terjadi dalam dunia usaha. Jadi koperasi harus selalu mengikuti perkembangan teknologi dan penguasaan informasi.

H1g: Jaringan pasar berpengaruh positif terhadap perkembangan usaha koperasi

\section{h. Jumlah dan Kualitas Sumber Daya Manusia Para Pengurus dan Manajer}

Menyatakan bahwa jumlah dan kualitas sumber daya manusia para pengurus dan manajer, koperasi umumnya dikelola oleh tim manajemen dengan status pendidikan yang tidak begitu tinggi, sehingga kemampuan manajerialnya juga kurang memadai. Apalagi pelatihan sebagai media penambah wawasan dan kemampuan manajerialnya belum tersedia secara optimal (Soedirman, 2006:3). Kualitas sumber daya koperasi merupakan suatu hal penting dalam perkembangan koperasi secara keseluruhan.

H1h: Jumlah dan Kualitas SDM Pengurus dan Manajer berpengaruh positif terhadap perkembangan usaha koperasi 


\section{i. Pemilikan dan Pemafaatan Perangkat Teknologi Produksi dan Informasi}

Pemilikan dan pemafaatan perangkat teknologi produksi dan informasi yang belum memadai, pada umumnya koperasi masih belum memiliki akses terhadap alat-alat komunikasi modern seperti jaringan internet. Banyak koperasi yang masih menggunakan manual sebagai piranti manajemennya sehingga cukup lamban dalam memberikan berbagai pelayanan kepada anggota. (Soedirman, 2006:4). Koperasi harus lebih tanggap dan lebih cepat dalam memperoleh informasi agar tidak tertinggal dengan badan usaha lain, karena untuk memenuhi keinginan anggota dan masyarakat koperasi dalam mengikuti perkembangan zaman.

H1i: Pemilikan dan pemanfaatan Perangkat Teknologi koperasi berpengaruh positif terhadap perkembangan usaha Koperasi

\section{j. Sistem manejemen}

Sistem manejemen yang baik adalah faktor yang paling penting untuk suksesnya koperasi. Pada saat menerapkan manejemen, pengurus mempunyai tanggung-jawab untuk merumuskan kebijaksanaan, menyetujui tanggung-jawab untuk merumuskan kebijaksanaan, menyetujui rencana dan program, melimpahkan wewenang kepada manajer (Sumarsono, 2003:124). Dapat disimpulkan bahwa dengan sistem manejemen yang baik akan dapat membuat koperasi berkembang menjadi lebih baik.

H1j: Sistem manajemen berpengaruh positif terhadap perkembangan usaha Koperasi

\section{k. Kinerja Pengurus}

Pengurus dalam koperasi mempunyai kedudukan yang sangat menentukan bagi keberhasilan koperasi sebagai organisasi ekonomi yang berwatak sosial. Pengurus koperasi dipilih dari dan oleh anggota koperasi dalam rapat anggota. Oleh karena itu kinerja pengurus mempunyai kedudukan yang menentukan keberhasilan koperasi (Sumarsono, 2003:124). Jadi dapat di- simpulkan bahwa dengan pengurus yang memiliki kompetensi yang baik akan dapat membuat koperasi berkembang menjadi lebih baik.

H1k: Kinerja pengurus koperasi berpengaruh positif terhadap perkembangan usaha Koperasi

\section{Kesamaan kepentingan ekonomi dari anggota}

Pada suatu koperasi faktor perekat yang sangat mendasar adalah kesamaan (homogenitas) kepentingan ekonomi dari para anggotanya. Signifikansi faktor ini tergambar jelas diperhatikan adanya fenomena bahwa seorang anggota yang telah berhasil dalam usahanya cenderung akan meninggalkan koperasi walaupun sebelumnya keberhasilan orang tersebut didukung sepenuhnya oleh koperasi. Peningkatan kemampuan menyebabkan orang berubah kepentingannya maka orang tersebut dapat pindah ke koperasi lain, yang dapat memenuhi kepentingannya. Dengan kata lain faktor homogenitas kepentingan anggota merupakan kata kunci dalam membangun koperasi.

H11: Kesamaan kepentingan ekonomi dari anggota berpengaruh positif terhadap perkembangan usaha Koperasi

\section{Faktor eksternal}

a. Komitmen pemerintah terhadap perkembangan usaha koperasi

Komitmen pemerintah untuk menempatkan koperasi sebagai soko guru perekonomian nasional. Kesenjangan yang terjadi dalam struktur ekonomi nasional mencerminkan tidak proposionalnya kebijakan pemerintah di dalam mengembangkan para pelaku ekonomi secara nasional. Hal ini ditunjukkan dengan dikuasainya sebagian besar asset usaha nasional oleh sebagian kecil kelompok usaha besar (Soedirman, 2006:2). Jadi dengan adanya kebijakan pemerintah disini koperasi masih dapat perhatian yang kecil, padahal koperasi memberikan omzet yang cukup besar dibanding dengan usaha swasta. 
H2a: Pengurus koperasi berpengaruh positif terhadap perkembangan usaha Koperasi

\section{b. Sistem prasarana, pelayanan, pendidikan dan penyuluhan.}

Pengetahuan anggota koperasi terhadap makna dan hakekat koperasi, manfaat koperasi, hak dan kewajiban anggota di dalam berkoperasi belum sepenuhnya dapat dikatakan baik. Pelatihan dan penyuluhan anggota untuk meningkatkan kualitas sumber daya insani anggota, meningkatkan kemampuan manajerial (Soedirman, 2006:3). Sebagian besar seorang anggota koperasi tidak mengetahui mengapa menjadi anggota koperasi. Dengan demikian memberikan pendidikan dan penyuluhan pada anggota sangat penting. H2b: Sistem prasaran, pelayanan, pendidikan dan penyuluhan berpengaruh positif terhadap perkembangan usaha koperasi

\section{c. Iklim pendukung perkembangan koperasi}

Menurut Sumarsono (2003:124) Suasana (iklim) untuk suburnya pertumbuhan koperasi tidak dapat datang begitu saja. Untuk itu pemerintah berusaha menciptakan suasana yang dapat mendorong pertumbuhan koperasi dengan cara mengadakan koordinasi-koordinasi. Dengan koordinasi-koordinasi tersebut dimaksudkan agar berbagai pihak yang ada sangkut pautnya dengan pertumbuhan koperasi dapat dihasilkan pandangannya.

H2c: Iklim pendukung perkembangan koperasi berpengaruh positif terhadap perkembangan usaha koperasi

\section{d. Dicabutnya Fasilitas Tertentu Oleh Pemerintah}

Menurut Soedirman (2006:6) bahwa Koperasi berkembang mengikuti perkembangan fasilitas yang diberikan oleh pemerintah, sehingga seakan-akan koperasi adalah organisasi yang sekedar menjalankan program-program pemerintah. Berbagai peluang usaha koperasi harus diakui belum secara optimal dapat dimanfaatkan oleh koperasi. Bahkan organisasi DEKOPIN yang diharapkan menjadi corong koperasi yang memperjuangkan aspirasi koperasi dan melaksanakan berbagai pelatihan. Dicabutnya fasilitas tertentu koperasi oleh pemerintah akibatnya koperasi tidak dapat lagi menjalankan usahanya dengan baik, misalnya usaha penyaluran pupuk yang pada waktu yang lalu disalurkan oleh koperasi melalui koperta sekarang tidak lagi sehingga koperasi terpaksa mencari sendiri ke Dolog.

H2d: Dicabutnya fasilitas tertentu oleh pemerintah berpengaruh positif terhadap perkembangan usaha koperasi

\section{e. Tingkat harga}

Menurut Sumarsono (2003:124) Tingkat harga yang selalu berubah (naik) menyebabkan pendapatan penjualan sekarang tidak dapat dimanfaatkan untuk meneruskan usaha, justru menciutkan usaha. Permasalahan tersebut merupakan faktor ancaman dan kelemahan koperasi baik internal dan eksternal. Berbagai kendala dan tantangan tersebut menyebabkan koperasi belum mampu berfungsi dan berperan sesuai harapan. Berbagai peraturan, kebijakan dan kesempatan atau peluang yang tersedia bagi koperasi belum dimanfaatkan oleh koperasi bagi kepentingan anggota dan masyarakat lingkungannya.

H2e: Tingkat harga berpengaruh positif terhadap perkembangan usaha Koperasi 
Gambar 1.

\section{Model Penelitian}

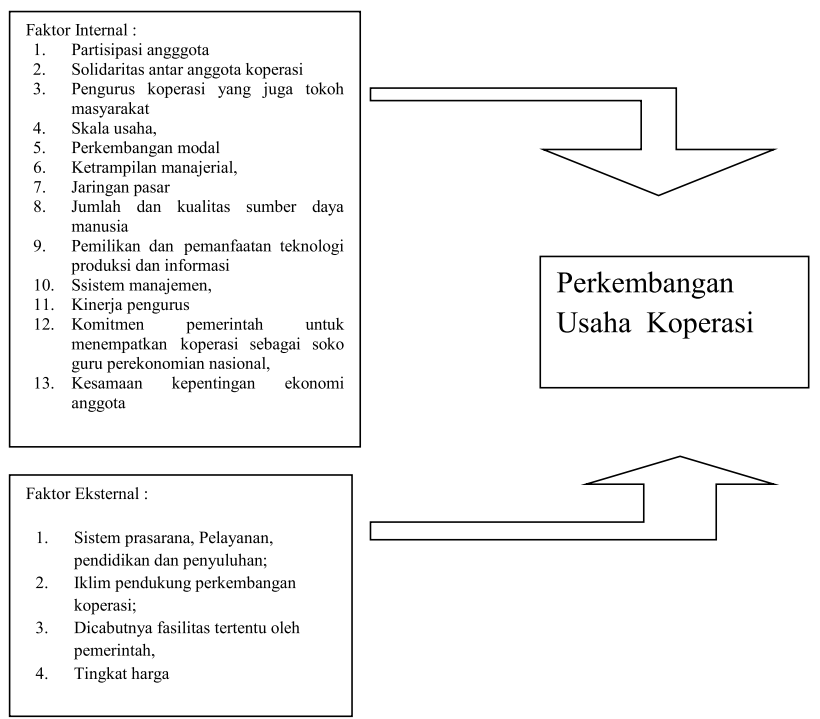

METODE PENELITIAN

\section{Jenis dan sumber data}

Penelitian ini menggunakan data primer untuk mendapatkan informasi mengenai semua variabel. Adapun sumber data yang digunakan dalam penelitian ini diperoleh dari Dinas Perindustrian Perdagangan dan Koperasi 2012. Data penelitian dilakukan dengan menyebar kuesioner melalui contact person. Responden menjawab pernyataan dengan skala likert 5 yaitu "Sangat Tidak Setuju (1)" sampai "Sangat Setuju (5)".

\section{Populasi dan sampel}

Populasi dalam penelitian ini adalah semua pengurus/manajer koperasi yang mempunyai wewenang dalam kepengurusan mulai dari ketua, bendahara dan sekretaris, yang terdaftar di dinas Deperindagkop Kota Magelang 2012. Jumlah koperasi di Magelang sebanyak 205. Teknik pengambilan sampel berupa Purposive Sampling yaitu dengan kriteria : 1) orang yang menjabat sebagai pengurus koperasi atau manajer; 2) orang yang mempunyai masa jabatan minimal satu ta- hun dengan alasan sudah dapat diketahui kinerjanya, dengan laporan yang dipertanggungjawabkan kepada anggota.

\section{Teknik Analisis Data}

Pada penelitian ini teknik analisis yang digunakan adalah teknik analisis data deskripsi kuantitatif, uji kualitas data dan untuk uji hipotesis menggunakan uji F, Uji T dan Uji Determinan R2

\section{HASIL PENELITIAN DAN PEMBAHASAN}

\section{Statistik Deskripsi}

Kuisioner yang disebar sebanyak 34 responden sesuai kriteria, responden yang tidak bersedia mengisi atau menolak sebanyak 4 (empat), yang tidak mengembalikan sebanyak 3 (tiga). Sampel yang diisi lengkap dan dapat diolah sebanyak 27 responden, dengan profil sebagai berikut :

Tabel 1

\section{Deskriptif Responden}

\begin{tabular}{llcr}
\hline & Kriteria & $\begin{array}{c}\text { Jumlah } \\
\text { Responden }\end{array}$ & Prosentase \\
\hline \multirow{2}{*}{ Usia } & 20 s.d. 40 th & 10 & $37,04 \%$ \\
& $>40$ th & 17 & $62,96 \%$ \\
\hline \multirow{2}{*}{ Jenis Kelamin } & Laki-laki & 22 & $81,50 \%$ \\
& Wanita & 5 & $18,50 \%$ \\
\multirow{4}{*}{ Tingkat Pendidikan } & SMP & 1 & $3,70 \%$ \\
& SMU & 10 & $11,11 \%$ \\
& Diploma & 3 & $37,04 \%$ \\
& S1 & 12 & $44,44 \%$ \\
\multirow{2}{*}{ Jabatan } & S2 & 1 & $3,70 \%$ \\
& Manajer & 19 & $70,37 \%$ \\
Lama Bekerja & Sekretaris & 3 & $11,11 \%$ \\
& Bendahara & 5 & $18,52 \%$ \\
\hline & $<10$ th & 22 & $81,48 \%$ \\
& 10 s.d-20 th & 3 & $11,11 \%$ \\
& $>20$ th & 2 & $07,41 \%$ \\
\hline
\end{tabular}

Sumber: Data primer yang diolah

Berdasarkan data tampak bahwa sebagian besar responden rata-rata usia diatas 40 tahun sebanyak 17 orang $(62,96 \%)$. Partisipasi responden dilihat dari jenis kelamin mayoritas laki-laki sebanyak 22 orang $(81,50 \%)$. Pada tingkat Pendidikan mayoritas partisipasi responden radalah $\mathrm{S} 1$ yaitu sebanyak 12 orang (44,44\%). Jabatan responden diperoleh mayoritas yang berpartisipasi adalah manajer sebanyak 19 orang $(70,37 \%)$. Adapun lama bekerja di koperasi mayoritas yang 
berpartisipasi pada masa kerja kurang dari 10 tahun sebanyak 22 orang $(81,48 \%)$.

\section{Uji Kualitas Data}

Uji Valliditas pada tabel 2 (terlampir) menunjukkan bahwa instrument variabel yang mempunyai nilai cronbach alpha $<5 \%$ dinyatakan valid. Pada beberapa instrument variabel dinyatakan tidak valid karena nilai cronbach alpha $>5 \%$, yaitu variabel $x 1$ (partisipasi anggota) yang teridiri dari 9 pernyataan, untuk no $1 \mathrm{~s} / \mathrm{d} 4$ dan no 7 dinyatakan tidak valid, variable $\mathrm{x} 3$ (pendidikan dan kepemimpinan koperasi) yang terdiri dari 8 pernyataan pada pernyataan no 6 tidak valid, variabel x10 (sistem manajemen) terdiri dari 9 pernyataan, pada pernyataan no 9 tidak valid. Pada butir pernyataan variabel yang hasilnya tidak valid, solusinya tidak akan diikutkan pada pengujian berikutnya.

Uji reliabilitas menggunakan koefisien Alpha Cronbach. Instrument suatu kuesioner dinyatakan reliabel apabila nilai koefisien Alpha Cronbach $>0,60$. Berdasarkan tabel 3 (terlampir) dapat diketahui bahwa semua instrument variabel penelitian dikatakan reliabel karena memiliki nilai Alpha Cronbach di atas 0,60 (Nunnanly, 1967 dalam Ghozali (2009).

\section{Hasil Uji Hipotesis}

Pengujian hipotesis dapat dilakukan dengan melihat hasil regresi berganda, dapat dilihat pada tabel 4 .

Berdasarkan hasil koefisien regresi tabel 4 diperoleh persamaan sebagai berikut:

$$
\begin{aligned}
Y= & -31,18-0,030 X_{1}+0,181 X_{2}+1,051 \\
& X_{3}-3,416 X_{4}+1,520 X_{5}+0,761 X_{6} \\
& -0,410 X_{7}+2,230 X_{8}-0,868 X_{9}+0,334 \\
& X_{10}+0,659 X_{11}-0,439 X_{12}-0,388 X_{13} \\
& +1,366 X_{14}-2,221 X_{15}+1,704 X_{16}+ \\
& 0,367 X_{17}
\end{aligned}
$$

\begin{tabular}{|c|c|c|c|c|c|c|}
\hline & \multirow{2}{*}{$\begin{array}{c}\text { Model } \\
\text { B }\end{array}$} & \multicolumn{2}{|c|}{$\begin{array}{c}\text { Unstandardized } \\
\text { Coefficients }\end{array}$} & \multirow[t]{2}{*}{$\begin{array}{l}\text { Standardized } \\
\text { Coefficients }\end{array}$} & \multirow[b]{2}{*}{$\mathrm{t}$} & \multirow[b]{2}{*}{ Sig. } \\
\hline & & Std. Error & Beta & & & \\
\hline \multirow[t]{18}{*}{1} & (Constant) & -31.118 & 18.923 & & -1.644 & .134 \\
\hline & $\mathrm{X}_{1}$ & -.030 & .306 & -.024 & -0.970 & .925 \\
\hline & $\mathrm{X}_{2}$ & .181 & .494 & .115 & 0.366 & .723 \\
\hline & $X_{3}$ & 1.051 & .364 & .879 & 2.890 & .018 \\
\hline & $\mathrm{X}_{4}$ & -3.416 & 2.749 & -1.051 & -1.243 & .245 \\
\hline & $\mathrm{X}_{5}$ & 1.520 & 1.092 & .698 & 1.392 & .197 \\
\hline & $X_{6}$ & .761 & .733 & .286 & 1.039 & .326 \\
\hline & $\mathrm{X}_{7}$ & -.410 & .516 & .222 & -0.794 & .448 \\
\hline & $\mathrm{X}_{8}$ & 2.230 & 2.759 & .751 & 0.808 & .440 \\
\hline & $\mathrm{X}_{9}$ & -.868 & .565 & -.644 & -1.536 & .159 \\
\hline & $\mathrm{X}_{10}$ & .334 & .365 & .310 & 0.916 & .384 \\
\hline & $\mathrm{X}_{11}$ & .659 & .435 & .381 & 1.514 & .164 \\
\hline & $\mathrm{X}_{12}$ & -.439 & .479 & -.261 & -0.917 & .383 \\
\hline & $\mathrm{X}_{13}$ & -.388 & .714 & -.167 & -.543 & .600 \\
\hline & $\mathrm{X}_{14}$ & 1.366 & .760 & .643 & 1.872 & .106 \\
\hline & $\mathrm{X}_{15}$ & -2.221 & 1.187 & -.632 & 1.798 & .094 \\
\hline & $\mathrm{X}_{16}$ & 1.704 & .756 & .555 & 2.255 & .051 \\
\hline & $\mathrm{X}_{17}$ & .367 & .388 & .264 & 0.948 & .368 \\
\hline
\end{tabular}

Tabel 4

Koefisien Regresi

Sumber: Data primer yang diolah, 2012

\section{HASIL PENELITIAN DAN PEMBAHASAN}

\section{Partisipasi anggota berpengaruh terhadap perkembangan usaha koperasi}

Hasil uji regresi menunjukkan bahwa variabel partisipasi anggota tidak signifikan secara statistik dimana probabilitas variabel ini sebesar 0,925 diatas 0.05 (5\%). Artinya analisis hasil menyatakan hipotesisi tidak diterima, sehingga dinyatakan partisipasi anggota tidak berpengaruh terhadap perkembangan usaha koperasi. Hasil penelitian tidak sejalan dengan teori yang ada yaitu anggota merupakan pemegang kekuasaan tertinggi sehingga anggota harus berperan serta dengan baik. Hasil menunjukkan anggota tidak banyak berperan dalam perkembangan usaha 
koperasi di Kota Magelang karena anggota pasif dan hanya melakukan kegiatan yang sifatnya rutinitas seperti iuran dan melakukan simpan pinjaman saja. Penelitian ini tidak mendukung penelitian Rahman (2006) yang menyatakan partisipasi anggota berpengaruh terhadap perkembangan usaha koperasi.

\section{Solidaritas antar anggota berpengaruh terhadap perkembangan usaha koperasi.}

Pengujian terhadap variabel solidaritas antar anggota ditemukan secara statistik tidak signifikan, dimana probabilitas variabel sebesar 0.366 diatas 0.05 (5\%). Hasil diartikan bahwa solidaritas antar anggota tidak berpengaruh terhadap perkembangan usaha koperasi. Anggota koperasi kurang peduli antar sesama anggota karena sifatnya hanya pasif kurang pertemuan sehingga kurang mempunyai rasa solidaritas sesama anggota. Temuan ini tidak mendukung hasil penelitian Ratna (2009) yaitu solidaritas antar anggota berpengaruh terhadap perkembangan koperasi

\section{Pendidikan dan kepemimpinan pengurus berpengaruh terhadap perkembangan usaha koperasi.}

Berdasarkan hasil statsitik hipotesis diterima dimana probabilitas variabel sebesar 0.018 lebih kecil dari 0.05 , artinya pendidikan dan kepemimpinan pengurus berpengaruh terhadap perkembangan usaha koperasi. Hasil penelitian ini sesuai dengan teori yaitu kualitas pengurus merupakan satu hal yang mampu menunjang terciptanya kemandirian koperasi, sehingga perlu diciptakan profesionalisme pada pengurus yaitu pendidikan dan kepemimpinannya.

Pengurus koperasi sangat berperan terhadap perkembangan suatu koperasi. Hidup matinya koperasi sangat ditentukan oleh peran pengurus, sehingga dibutuhkan pengurus yang baik dan kualitas. Koperasi akan maju selama peran pengurus berjalan dengan baik dan koperasi bukan menjadi pekerjaan sambilan. Pada kenyataan pengurus koperasi hanya mengemban sebatas penunjukkan tidak maksimal dalam bekerja mengemban amanah. Apabila pada saat semua pengurus di kota Magelang mengelola dan melaksanakan amanah dengan baik serta mempertanggungjawabkan kepada anggota dan pengawas serta ada unsur ikhlas maka tidak akan terdapat koperasi yang tutup atau mati.

\section{Skala usaha berpengaruh terhadap per- kembangan usaha koperasi.}

Berdasarkan hasil statistik ditemukan variabel skala usaha tidak signifikan yaitu nilai alpha sebesar 0.245 lebih besar dari 0.05 sehingga hipotesis tidak diterima, artinya skala usaha tidak berpengaruh terhadap perkembangan usaha koperasi. Koperasi yang ada masih hanya mengandalkan proyek dari pemerintah. Koperasi belum mampu bersaing dengan lainnya dan belum mampu membuktikan akan daya saing yang dimiliki. Penelitian ini tidak mendukung dari hasil penelitian Handayani (2007).

\section{Perkembangan modal berpengaruh terhadap perkembangan usaha koperasi.}

Pengujian terhadap variabel perkembangan modal ditemukan secara statistik tidak signifikan dimana probabilitas menunjukkan 0.197 lebih besar dari 5\% sehingga hipotesis tidak diterima, artinya perkembangan modal tidak berpengaruh terhadap perkembangan usaha koperasi. Hasil peneitian ini bertentangan dengan konsep teori yang ada, bahwa koperasi sangat membutuhkan dana atau tergantung dari dana yang dimiliki sehingga akan berkembang dengan baik. Modal koperasi yang ada berasal dari simpanan pokok, simpanan wajib, simpanan cadangan dan simpanan hibah. Modal yang ada akan menjadikan penopang dan pemupukan sehingga memperkuat kegiatan usaha. Penelitian ini tidak mendukung dari hasil penelitian Handayani (2007). 
Ketrampilan manajerial berpengaruh terhadap perkembangan usaha koperasi.

Hasil penelitian menunjukkan bahwa secara statistik nilai alpha diatas $5 \%$ yaitu 0.326 sehingga hipotesis tidak diterima, artinya ketrampilan manajerial sebagai faktor internal tidak berpengaruh terhadap perkembangan usaha koperasi. Secara konsep teori pada dasarnya koperasi memerlukan tenaga manajer untuk menjalankan usahanya. Peran manajer menjadi lebih penting apabila volume usaha besar, sehingga menjadi pertimbangan suatu koperasi apakah diperlukan manajer atau tidak. Kenyataannya manajer masih dirangkap oleh pengurus sehingga tidak maksimal dalam mengembangkan usaha koperasi dan hasil penelitian ini menyatakan tidak berpengaruh terhadap usaha koperasi. Penelitian ini tidak mendukung dari hasil penelitian Rachman (2009).

\section{Jaringan Pasar berpengaruh terhadap perkembangan usaha koperasi.}

Berdasarkan hasil statistik nilai alpha sebesar 0.448 diatas 5\% sehingga hipotesis tidak diterima, artinya bahwa jaringan pasar tidak berpengaruh terhadap perkembangan usaha koperasi. Koperasi belum siap dan belum menyelenggarakan kerjasama memperkuat jaringan sebagai perluasan usaha. Koperasi masih menjalankan usahanya sekedar simpan pinjam belum melakukan usaha yang lain dan kerjasama yang masih terbatas.Hasil penelitian mendukung dari penelitian Handayani (2007)

\section{Kualitas dan kuantitas SDM berpengaruh terhadap perkembangan usaha koperasi.}

Hasil penelitian menunjukkan bahwa secara statistik nilai alpha sebesar 0.440 adalah diatas 5\% sehingga hipotesis tidak diterima, artinya kualitas dan kuantitas SDM tidak berpengaruh terhadap perkembangan usaha koperasi.Hasil penelitian tidak sesuai dengan konsep teori bahwa sumber daya manusia akan mempengaruhi keberadaan bahkan perkembangan koperasi, hal ini disebabkan banyak SDM yang melaksanakan koperasi hanya pekerjaan sambilan, misalnya pegawai menjadi pengurus sehingga kurang maksimal dalam memikirkan koperasi.

Pemilikan dan pemanfaatan perangkat teknologi produksi dan informasi berpengaruh terhadap perkembangan usaha koperasi.

Pengujian terhadap variabel pemilikan dan pemanfaatan perangkat teknologi produksi dan informasi hasil penelitian menunjukkan secara statistik nilai alpha sebesar 0.159 diatas 5\% sehingga hipotesis tidak diterima. Hasil penelitian menyatakan bahwa pemilikan dan pemanfaatan perangkat teknologi produksi dan informasi tidak berpengaruh terhadap perkembangan usaha koperasi. Dikatakan koperasi belum memanfaatkan teknologi dengan baik, karena masih menggunakan sarana yang kurang memadai dan seadanya.

\section{Sistem manajemen berpengaruh terhadap perkembangan usaha koperasi.}

Hasil penelitian menunjukkan bahwa secara statistik alpha 0.384 diatas 5\% sehingga hipotesis tidak diterima, artinya sistem manajemen tidak berpengaruh terhadap perkembangan koperasi. Hasil penelitian tidak sesuai dengan konsep teori yang menyatakan bahwa manajemen yang baik adalah faktor yang paling penting untuk suksesnya koperasi. Sistem manajemen yang baik yaitu sistem manajemen partisipasi dan manajemen kewirausahaan, yang semua ini belum dimiliki oleh koperasi. Penelitian ini mendukung dari hasil penelitian Handayani (2007)

\section{Kinerja pengurus berpengaruh terhadap perkembangan usaha koperasi.}

Hasil penelitian menunjukkan bahwa secara statistik nilai alpha diatas 5\% sehingga hipotesis tidak diterima, artinya kinerja pengurus tidak berpengaruh terhadap perkembangan usaha koperasi. Pengurus belum melihatkan kinerjanya terhadap perkembangan koperasi, dapat dilihat 
dari kondisi koperasi di Magelang banyak yang kurang sehat atau tidak berkembang karena tidak terlaksana tugas dari pengurus.

Kesamaan kepentingan ekonomi anggota berpengaruh terhadap perkembangan usaha koperasi.

Hasil penelitian menunjukkan bahwa secara statistic alpha diatas $5 \%$ sehingga hipotesis ditolak, artinya kesamaan kepentingan ekonomi anggota tidak berpengaruh terhadap perkembanganusahakoperasi.Hasilmenunjukkan bahwa perkembangan koperasi tidak dipengaruhi apakah masing-masing anggota mempunyai kepentingan ekonomi. Kebanyakan anggota tidak memikirkan orang lain dalam berkoperasi karena sifatnya hanya melakukan simpan pinjam dan menyetorkan modal yang akan menunggu hasil usaha, dan kurang merasa kebersamaan sebagai dasar asas koperasi.

\section{Komitmen pemerintah berpengaruh terhadap perkembangan usaha koperasi.}

Hasil penelitian menunjukkan bahwa secara statistik nilai alpha diatas 5\% sehingga hipotesis penelitian ditolak, artinya komitmen pemerintah tidak berpengaruh terhadap perkembangan usaha koperasi. Secara riil pemerintah mempunyai peran besar terhadap koperasi yaitu dalam penetapan perundang-undangan dan peraturan koperasi. Peran pemerintah cenderung lebih kearah intervensi struktural dan pengisian jabatan strategi koperasi dengan orang-orang pemerintahan/pengusaha. Kondisi ini yang menyebabkan pemerintah kurang melaksanakan komitmennya dalam mengembangkan usaha koperasi sebagai usaha yang mensejahterakan rakyat atau soko guru perekonomian. Hasil penelitian ini tidak mendukung penelitian Rahman (2006) yaitu komitmen pemerintah berpengaruh terhadap perkembangan koperasi, tetapi mendukung penelitian Handayani (2007).
Sistem prasarana, pelayanan, pendidikan dan penyuluhan berpengaruh terhadap perkembangan usaha koperasi.

Hasil penelitian menunjukkan bahwa secara statistik nilai alpha diatas 5\% sehingga hipotesis ditolak, artinya sistem prasarana, pelayanan, pendidikan dan penyuluhan tidak berpengaruh terhadap perkembangan usaha koperasi. Hasil penelitian tidak mendukung konsep teori yang ada bahwa adanya prasarana, pelayanan, pendidikan dan penyuluhan seharusnya berpengaruh terhadap perkembangan koperasi. Hasil penelitian ini tidak mendukung penelitian Handayani (2007).

\section{Iklim pendukung berpengaruh terhadap perkembangan usaha koperasi.}

Hasil penelitian menunjukkan bahwa secara statistik nilai alpha pada tabel mempunyai angka diatas 5\% sehingga hipotesis ditolak, artinya iklim pendukung tidak berpengaruh terhadap perkembangan usaha koperasi. Penelitian ini tidak sesuai dengan konsep teori bahwa iklim pendukung seharusnya berpengaruh terhadap perkembangan koperasi. Hasil penelitian menolak hipotesis karena iklim pendukung untuk koperasi kurang terutama di Kota Magelang terutama untuk iklim antar koperasi tidak ada saling kerjasama dan memotivasi. Penelitian ini tidak mendukung dari penelitian Rahman (2006), tetapi hasilnya menyatakan iklim usaha sebagai pendukung berpengaruh kecil.

Dicabutnya fasilitas tertentu oleh pemerintah berpengaruh terhadap perkembangan usaha koperasi.

Hasil penelitian menunjukkan bahwa secara statistik nilai alpha 0.051 dibulatkan sama dengan 5\% sehingga hipotesis dapat diterima, artinya dicabutnya fasilitas tertentu oleh pemerintah akan berpengaruh terhadap perkembangan usaha koperasi. Penelitian ini menggambar- 
kan bahwa faktor yang terkait dengan komitmen pemerintah berpengaruh terhadap perkembangan koperasi sehingga faktor fasilitas tertentu dicabut pemerintah berpengaruh terhadap perkembangan koperasi, sedangkan koperasi masih mengandalkan bantuan dari pemerintah yang sangat mendominasi.

\section{Tingkat harga berpengaruh terhadap perkembangan usaha koperasi.}

Hasil penelitian menunjukkan secara statistik nilai alpha diatas 5\% sehingga hipotesis tidak diterima, artinya tingkat harga tidak berpengaruh tehadap perkembangan usaha koperasi, disebabkan koperasi kurang dalam melakukan usaha sehingga tidak dipengaruhi oleh tingkat harga. Koperasi yang mengisi kuisioner adalah mayoritas koperasi simpan pinjam sehingga tidak dipengaruhi oleh harga karena tidak melaksanakan usaha penjualan barang.

\section{KESIMPULAN DAN SARAN}

Berdasarkan pembahasan hasil penelitian dapat dikemukakan beberapa kesimpulan:

1. Faktor internal hanya variabel pendidikan dan kepemimpinan pengurus berpengaruh terhadap perkembangan usaha koperasi. Kualitas pengurus akan sangat membantu lancarnya keberhasilan usaha koperasi.

2. Faktor ekternal hanya variabel dicabutnya fasilitas oleh pemerintah yang berpengaruh terhadap perkembangan usaha koperasi.

3. Uji Adjusted $R$ Square sebesar 0,349 atau $34,9 \%$ berarti variabel perkembangan usaha koperasi hanya dipengaruhi dari variabel faktor internal dan eksternal sebesar 34,9\% sedangkan sebanyak 65,1\% (100\%-34,9\%) perkembangan usaha koperasi dijelaskan oleh faktor lain diluar penelitian ini.

Berdasarkan hasil penelitian ada beberapa hal yang dapat disarankan yaitu :

1. Masih ada indikator variabel yang tidak valid untuk kuisioner karena beberapa kuisioner dikembangkan sendiri berdasarkan konsep yang ada. Penelitian selanjutnya menggunakan referensi terbaru untuk indikator kuisioner dan perlu menguji respon bias.

2. Penelitian menggunakan sampel pengurus atau manajer, sedangkan koperasi di Kota Magelang banyak yang tidak memiliki manajer dan pengurus yang aktif, sehingga dalam pengisian masih kurang meyakinkan, perlu menggunakan anggota/pengawas koperasi sebagai responden.

3. Penelitian hanya dilakukan di Kota Magelang, sehingga hasilnya belum maksimal untuk menjelaskan perkembangan koperasi terutama seluruh Magelang. Penelitian selanjutnya dapat mengambil lokasi yang lebih luas agar lebih mengeneralisasi.

4. Pengurus perlu lebih aktif dalam menjalankan tugas dan kewajibannya dengan memonitor, mengevaluasi kebutuhan dan keinginan anggota secara kontinyu, sehingga pelayanan sesuai yang diharapkan anggota.

5. Perlu diadakan pendidikan dan latihan kerja yang lebih intensif untuk pengelola meningkatkan pengetahuan dan keterampilan dalam mengelola koperasi.

\section{DAFTAR PUSTAKA}

Amelia, 2001. Peranan Aktivitas Credit Union Dalam Pemberdayaan Ekonomi Rakyat. Tesis (S-2) Tidak Dipublikasikan. Medan. Program Magister Studi Pembangunan Fakultas Ilmu Sosial danIlmu Politik Universitas Sumatera Utara (FISIP-USU).

Anonimus, (2006). Kumpulan hasil-hasil Workshop Pemberdayaan Koperasi dan UMKM. Deputi Bidang Pengkajian Sumberdaya Koperasi dan UMKM.

Anoraga, Pandji dan Sudantoko, Djoko. 2002. Koperasi, Kewirausahaan dan Usaha Kecil. Rineka Cipta. Jakarta. 
Arikunto, Suharsimi. 2002. Metodologi Penelitian.Penerbit Salemba

Badaruddin \& Nasution, M. Arief. 2005. "Modal sosial dan Pemberdayaan Komunitas Nelayan (Isu-isunKelautan dan Kemiskinan Hingga Bajak Laut).Yogyakarta.PustakaPelajar. Firdaus dan Agus Edhi S. 2004 "Perkoperasian Indonesia". Penerbit Andi Offsed

Handayani, Sri. 2007. Analisis Faktor-faktor yang Mempengaruhi Perkembangan Usaha Koperasi Aneka Bakti Surabaya di PT. PJB (Pembangkit Jawa Bali), Jurnal pada $\underline{w w w . g o o g l e . c o m}$.

Mubyarto. 2003. Reformasi sistem Ekonomi, dari Kapitalisme Menuju Ekonomi Kerakyatan Yogyakarta: Aditya Media.

Ngo, A. Petrus. 2002. Ketua Credit Union Daya Lestari Samarinda, Mengapa harus Credit Union?, Makalah disampaikan pada Seminar Pendalaman Ekonomi Rakyat, Jakarta

Nasution Muslimin, (2001). Koperasi, Konsepsi Pemikiran dan Peluang Pembangunan Masa Depan Bangsa.

Rachman. 2006. Analisis Faktor-faktor Yang Mempengaruhi Perkembangan Usaha Koperasi (Survey Pada KUD di Kab. Bandung).
Soedirman. 2006. Membangun Koperasi Sebagai Wahana Efektif UntukMemberdayakan Perekonomian Rakyat. Badan Perencanaan Pembangunan Nasional Jakarta.

Sumarsono, Sonny 2003. Koperasi Indonesia. Penerbit Erlangga. Jakarta

Surya Dharma Ali, (2007). Komitmen Pemberdayaan UMKM dan Koperasi. Disampaikan pada Seminar Prospek Usaha Kecil dan Menengah, Lembaga Usaha Pengembangan Masyarakat Jakarta.

Sukardi, Sritua Arif 2003. Ekonomi Rakyat di Era Globalisasi. Makalah disampaikanPada Seminar Sehari Memperingati 100 hari Meninggalnya Prof. Dr. Sritua Arif. Medan, FISIP USU.

Titus, K. Kurniadi. 2004. Ekonomi Rakyat. Makalah Pendahuluan Pada Seminar Ekonomi Rakyat, Lembaga Keuangan Mikro.

Widiyanti, Ninik. 2002. Manajemen Koperasi. Jakarta: Rineka Cipta. 